\title{
Toward an integrative framework for local development path analysis
}

\author{
Alastair W. Moore $^{1,2}$, Leslie King $^{2}$, Ann Dale $^{2}$ and $\underline{\text { Robert Newell }}^{2}$
}

\begin{abstract}
Despite decades of debate and policy interventions, the wicked social-ecological problem of anthropogenic climate change continues to threaten the sustainability of local communities. Impacts resulting from a rapidly changing climate are now inevitable yet variable in their nature and timing, depending on the extent to which local communities can respond. Transforming to low-carbon communities requires the ability to interrupt the inertia in existing development paths and shift these to more sustainable trajectories. Intervening in local development paths to mitigate climate change requires understanding the multilevel interactions between actors, practices, structures, and ecosystems implicated in system transformations. In this paper we explore the synergies between the multilevel perspective on transitions, social-ecological systems thinking, and social practice theories. We use these to conceptualize an integrative analytical framework capable of assisting researchers and local governments to understand how development path trajectories are sustained, and hence, which local climate initiatives are more likely to change the inertia of current development paths, and which ones only tinker at their edges.
\end{abstract}

Key Words: development path change; multilevel perspective; social practices; social-ecological systems; sustainability; transformation

\section{INTRODUCTION}

The December 2015 COP 21 negotiations resulted in an aspirational commitment to limit the increase in the global average temperature to $1.5^{\circ} \mathrm{C}$ (UNFCCC 2015). It is clear, however, that we need to dramatically change our current development path trajectories if we are to achieve this objective. This need for change can be considered particularly critical in light of the fact that current intended nationally determined contributions (INDCs), are seen by many as "reach" targets for greenhouse gas $(\mathrm{GHG})$ emission reductions, yet still result in between $2.7^{\circ}$ and $3^{\circ} \mathrm{C}$ of global warming by century's end (UNFCCC 2015). These plans fall short of the IPCC's COP 21 consensus targets of "well below $2^{\circ} \mathrm{C}$ above pre-industrial levels and pursuing efforts to limit the temperature increase to $1.5^{\circ} \mathrm{C}$ " (UNFCCC 2015:2), and far away from what others claim is critical, a carbon neutral economy by 2050 (WWF 2011, B Team 2015, The Elders 2015).

There are numerous examples of social and technological innovations at the local community level (Castán Broto and Bulkeley 2013) that strive to mitigate and adapt to climate change, e.g., solar hot water heating, green roofs, bicycling infrastructure, green "fee"-bates, carbon reserve funds, etc. However, it is difficult to know which of these will address what Levin et al. (2012) refer to as "a super wicked problem," that is, one where solutions are sought by the problem's creators, central authority for addressing the problem is weak or nonexistent, action is delayed because of discounting its severity, and time is running out. Understanding the relationship between these innovations, development path change, and transformative change is an urgent challenge. The degree and impact, as well as the timing of change in development paths is interpreted differently by different observers and scholars; what for some constitutes transformative change, others consider merely incremental or status quo, for example, the use of nuclear energy in moving to a low-carbon economy or a carbon neutral economy. Similarly, some consider a low-carbon economy to be transformative, and others merely a transitional phase because they believe the only possible way to transform the energy system is by moving to carbon neutrality. These judgements may depend on different starting points (what is the baseline) as well as the outcomes or impacts of the change in development path. It is clear that in the absence of clear definitions and criteria for analyzing "change" in development paths, we shall remain in the dark about the potential contribution of planned interventions to alter development pathways. We argue that because of the increasingly coevolving nature of human and natural systems and the magnitude of human impacts on social-ecological systems that our species is now at a stage in its evolution where it must deliberately and intentionally intervene in current development path trajectories.

Four notable system conditions complicate the study of transforming current development trajectories. First, climate change is an inherently complex problem that requires understanding the dynamic relationships between social, political, economic, and ecological dimensions (Cash et al. 2006). Second, investigating changes in development paths presents challenges in terms of how to identify and measure the continuum from superficial change to radical system transformation (Dale, Potvin, Mousseau, et al., e-Dialogue, https://www.

changingtheconversation.ca/node/73). Third, certain underlying forces that influence unsustainable development paths, such as technological lock-in and path dependency, can seem invisible and difficult to address, particularly at local scales (Unruh 2000, Bulkeley 2010, Castán Broto and Bulkeley 2013). The fourth condition is the relative powerlessness of local governments to influence change in the face of global dynamics and institutions (such as the WTO). Given these difficulties, local governments struggle to decide when and where to intervene in a particular system, what actions to take when (or if) they find the leverage points, how to enlist the support of other levels of government, and finally, which outcomes are indicative of incremental, transitional, or transformative change. Processes of interplay within and among different levels of societal organization can 
counteract these forces but too often work to the disadvantage of local governments when their actions are limited or undermined by powerful institutions operating against them. In the face of these obstacles, evaluating options based on an understanding of which new strategy, plan, program, or initiative might contribute to a more climate-friendly or sustainable trajectory remains challenging without an integrative framework that incorporates place, people, and politics.

Linked social-ecological systems inevitably change with a changing climate. The question is, can local governments steer such change to ensure sustainability of these systems? In order to tackle such a challenge, we first need to understand the nature of these changes, and be able to effectively interrogate the complexities inherent in development path transformation. We need to recognize whether such change simply consists of modest, incremental steps or leads to socio-technical system transformation. As a result of the rigidity of regimes, pathdependency, and lock-in, truly radical alterations are relatively rare (Geels 2010, Vergragt and Brown 2012). Where low-carbon transitions are concerned, socio-technical systems tend toward incremental change along predictable trajectories, following existing curves; there is rarely a shifting from one development curve (or trajectory) to another (Dale, unpublished manuscript)

Addressing climate change is not about turning the corner and going from a high emissions trajectory to a lower one; rather, it's about moving to a carbon neutral economy. But, what kind of changes are necessary at the local level? More critically, is it possible for governments to intentionally intervene when we do not have a way of analyzing existing development paths? Questions such as how a community jumps from one path to another, what processes are involved, and what evidence of such jumps can be observed, are fundamental for moving to a carbon neutral economy, and accordingly, an analytical framework is needed that enables us to answer these questions.

This paper explores a framework for assessing development path change, and unpacking the complex socio-technical systems, regimes, and everyday social practices that constitute development paths. Currently, scholarly consensus does not exist around what a transformation specifically entails (Moore et al. 2014). However, aspects of change can still be examined and understood through integrating and employing established theories around human and ecological dynamics. For example, Olsson et al. (2006) use a social-ecological perspective to examine key factors involved in governance change and transformation, such as knowledge building, networking, and leadership. Moore et al. (2014) detail an approach for understanding transformation of social-ecological systems by combining perspectives from literature on social movements, transition management, and social innovation. Foxon et al. (2009) employ the concepts of adaptive management and transition management to describe different perspectives on managing and governing change, and how users of these perspectives can learn from one another. The proposed framework builds upon the work of Hertz and Schlüter's (2015) on frameworks (as boundary objects) capable of reconciling ontological assumptions and bridging disciplinebased vocabularies. It also responds to the call for more integrated tools for interrogating transformative change (Future Earth 2014), and goes beyond the examination by Westley et al. (2013) of agency in social-ecological system transformations, and Patterson et al.'s (2017) exploration of the role of politics and governance, to include consideration of the interactions between scale dynamics, actor performances and relations, power distributions, and notions of place, in driving development path trajectories at the local level.

Similar to the research described above, we also draw from established theory and select three conceptual frames that we deem particularly useful for providing insights into the nature and nuances of change in development paths: social practice theories (SPT), social-ecological systems (SES), and the multilevel perspective (MLP) on transitions. They were specifically selected because of their differences in perspective and focus, and because they allow for complementary analysis and a deeper understanding of change. SPT examines social phenomena through practices, and elucidates how performances (and relationships between these) can result in certain development paths. SES thinking characterizes the world as a series of dynamic, interconnected human and ecological systems, and introduces the elements of interdependency between human and natural systems and change over time. MLP captures an often missing perspective on interplay, power, and conflict between levels of government in the sustainability literature (Geels 2014). The latter is particularly important given the number of scholars who argue that governance, and governments themselves, constitute some of the most critical issues facing both climate and sustainable development inaction (Dale and Hill 2001, Betsill and Bulkeley 2007, Burch 2010, Hodson and Marvin 2010, Murray and King 2012).

\section{DEVELOPMENT PATHS}

Intergovernmental Panel on Climate Change (IPCC 2007:696) refer to a development path as "a complex array of technological, economic, social, institutional, cultural, and biophysical characteristics that determines the interactions between human and natural systems, including consumption and production patterns in all countries, over time at a particular scale." Rather than determining "interactions between human and natural systems," development paths might more usefully be considered as both the cause and the outcome of these interactions. One way to understand a development path is to think of it as a dynamic array of reinforcing principles, values, materialities, and collective projects that steer development (Smith et al. 2010). Development paths reflect our collective socio-cultural values, and dominant socio-political structures (Muñoz-Erickson 2014). It should be noted that there is no one single right development path, rather, there are multiple paths (Muñoz-Erickson 2014) for the possible futures of communities. They result from complex interdependencies among multiple actors, institutions, and markets and are reinforced or opened up by socio-technical regimes. Current development trajectories reflect the unique intersection of purposive development decisions made many decades ago, and extra-societal forces and trends beyond our predecessors' control. Although we can refer to some unsustainable decisions and supporting policies made in the past, e.g., wide-scale commitment to infinite economic growth, persistent reliance on the internal combustion engine, etc., the fact that we are experiencing a raft of persistent tensions today confirms that current trajectories are usually maintained via strong self-reinforcing positive feedbacks. These feedbacks 
circulate among a highly interdependent suite of system components, and are the product of many variables and forces related to technological lock-in, historical bias, and society's collective values and actions.

Other scholars refer to development paths, such as the framework ISSC and UNESCO (2013) propose for pathways to equitable and sustainable development employing the concept of social and planetary boundaries, integrated with direction, diversity, and distribution. Although this is a powerful framework, particularly the integration of planetary boundaries and social boundaries, we do not necessarily agree with their classification of social boundaries, but concur with them that "identifying these critical Earth system processes, understanding their dynamic interactions at local, regional and global scales, and proposing boundary levels that avoid key 'tipping points', or biophysical thresholds" (ISSC and UNESCO 2013:84) is essential. We are proposing a framework that navigates among multiple levels and considers the integration of social practices as critical to transformative social change that sustains and ideally, in some cases, regenerates ecological systems.

Overcoming the trajectories of existing socio-technical regimes requires altering what Smith et al. (2010) consider three key momentum factors: mass (actors, materialities, infrastructures), speed (rate at which socio-technical developments arise), direction (overall performance of system innovations). We suggest adding to this list, collective will (borne of human frustration with persistent ecological and social crises) to transform toward a sustainable future. The inertia of socio-technical systems relies on the involvement of human actors and organizations who conduct themselves in the context of normative rules and institutions (Geels 2004), and any attempt to interrupt the inertia of the system requires a long-term, systems-level view that recognizes the interdependencies of actors, technologies and institutions, the importance of social learning, and the nonlinear trajectories of niche innovations (Loorbach and Rotmans 2010, Frantzeskaki et al. 2012, Burch et al. 2014). Thus, augmenting our understanding of the structure and motive force behind these paths is essential if local governments are to change or transform current unsustainable development paths; it requires understanding the actors, regime rules, and social-ecological system dynamics that drive these paths.

In the context of local community development, Burch et al. (2014) apply multilevel governance and systems lenses to their conceptualization of development paths. The former lens explicitly focuses on the role of politics, policies, and intergovernmental relations in path inertia and moves to more sustainable patterns of consumption and production (Markard et al. 2012). Governments at all levels reinforce existing trajectories through long-term, a priori decisions and public investment in social and technical infrastructures. In addition, conceptualizations of change need to be aware of the interdependencies and interactions among governing bodies. For example, local level decisions and actions can occur as a response to regional policies (Burch et al. 2014, Shaw et al. 2014, Dale et al. 2018). Therefore, any analysis of changes in development paths needs to reflect the fact that government institutions are part of the dominant regime and act through numerous arms and divisions, and at every level, from local to global (Bulkeley 2005).
Conceptualizing development path dynamics from a systems perspective builds on transition literature studies (Kemp et al. 2001, Rotmans et al. 2001, Shove and Walker 2007, Holtz et al. 2008), previous attempts to integrate SES and MLP (Lutz and Schachinger 2013, Mühlemeier and Binder 2016, Wolfram and Frantzeskaki 2016), and efforts to conceptualize different types of system change (Brown and Vergragt 2013, Gillard et al. 2016). Such works emphasize the nonlinearity of change at multiple socio-technical levels, the importance of novel experimentation and innovation, the presence of institutional barriers to change, and governance challenges encountered when encouraging more sustainable development paths (Markard et al. 2012, Burch et al. 2014). Applying a systems lens to development path transformation also serves to broaden the unit of analysis from the traditional level of technological artefact and innovation, to include whole socio-technical systems, or more specifically, "the linkages between a multitude of elements (such as artefacts, knowledge, capital, labor, cultural meaning, etc.), all of which are necessary for society to function" (Burch et al. 2014:469). The current authors agree with Burch et al. (2014) that these interlinked elements, while vital for societal functioning, also support institutional inertia and can contribute to decisionmaking gridlock at all levels of government (Dale and Newman 2007, Dale 2008).

When attempting to understand changes in development paths, it is important to consider multiple scales and levels, system effects, and as many sources of change as possible. Therefore, although interrogating development paths from a systems and governance perspective is useful, doing so does require a degree of abstraction that potentially leaves this approach with two significant blind spots. First, such a framing fails to account for ecological system dynamics, and second, the collective agency of actors, or indeed objects (Latour 2005), is taken for granted and not explicitly addressed. We argue that the force that comes from the aggregated daily activities, both intentional and unintentional, of all the people living in a community, coupled with environmental feedbacks must be included in the study of development paths. Exploring these effects can elucidate what makes a community or society orient their trajectory, and whether a path can be intentionally changed. Furthermore, it is also important to understand intentionality and whether there is a certain degree of conscious commitment toward change necessary for making it occur (Dale, Potvin, Mousseau, et al., eDialogue). Such considerations allow us to better understand critical intervention points in development paths and the collective role individual actors play in accelerating tipping points through changes in social practices.

Building upon the above discussion, we define a development path as one that

- operates at the scale of socio-technical systems and systems of governance, which consist of social systems (formal and informal rules, habits, and norms), networks amongst actors, diverse technologies, and ecological systems;

- is an emergent property of a system, imbued with values, norms, rules, and habits rather than a measurable set of conditions/characteristics;

- exhibits a particular set of interlinking regime rules and behaviors, including inertia and cascading effects over time; 
- is reinforced at multiple levels, with varied capacities and constraints on local agency occurring at each level;

- at its base, is coconstituted by individual actors and their daily activities or practices;

- is a driver of change (linear, nonlinear, and emergent) in inextricably coupled ecological and social systems.

\section{EXAMINING DEVELOPMENT PATH CHANGE}

The development path definition presented above illustrates their complexity and how they are layered with social, political, cultural, economic, and ecological dimensions. Climate solutions are beyond any one sector, any one level of government, and any one disciplinary perspective to solve (Dale and Hill 2001). These challenges are multiscalar, cross-border, and require unprecedented levels of collaboration between governments - local, regional, national and global - and necessitate the full support of civil society to implement solutions at these multiple scales (Dale et al. 2018). Complex interdependencies and interrelations need to be reconciled to realize simultaneous climate and sustainability imperatives. Traditional reductionist methodologies of earlier scholarship were not designed for understanding the entanglements found between complex system dynamics and human systems, thus resulting in an incomplete understanding of human-ecological interdependencies, coevolutionary processes, and limits. Without a more integrated understanding, we ignore critical system conditions necessary for all life; what Rockström and colleagues refer to as the safe operating space for humanity (Rockström et al. 2009), and other scholars have debated as the contested concept of ecological limits (Norgaard 1995, Davidson 2000, Brown et al. 2011).

In light of the discussion above, effective analysis of development path change for climate action mitigation and adaptation requires an integrative framework that can capture a wide variety of factors. To this end, we selected three theoretical perspectives that we believe complement one another in a manner that allows for comprehensiveness in investigations around development path change. Although they differ significantly in their foci, each perspective has direct applicability to researching the complex nature of coevolving ecological and human systems (Norgaard 1994).

We unpack the epistemological frames of social practice theories, social-ecological systems thinking, and the multilevel perspective on transitions to reveal their potential for contributing to understanding changing development paths, and to explore the possibility of developing an integrative framework for addressing the challenge of analyzing and assessing development paths. This challenge arises from the necessity to change local development path trajectories, while not having a conceptual scheme that allows researchers and local governments to comment on or systematically analyze the multiscalar, subject/structure/ ecosystem interactions that maintain them. Using this framework in forthcoming case study fieldwork, we anticipate that we can develop a more comprehensive understanding of how and when local governments can intentionally intervene in current development paths to transition, and ultimately transform, to the necessary critical conditions for keeping the increase in global average temperature to within a $1.5^{\circ} \mathrm{C}$ limit. Integration of these three perspectives ensures consideration of place, people, and politics and leads to collection of "thicker" data.

\section{Social-ecological systems}

The SES framework (Berkes et al. 2002, Walker et al. 2004, Folke et al. 2005, Bondizio et al. 2009, Cote and Nightingale 2012) captures interdependencies between humans and their surrounding ecosystems, which is particularly important in terms of engaging with the "place" context of local climate change impacts. SES introduces the concept of nested systems, and characterizes the interrelationship of systems from one level to another and the formation of networks, as more web-like than layered (Olsson et al. 2004, Cash et al. 2006). The concepts of nested levels and cross-scale interactions provide a suitable avenue for analyzing the effects of drivers originating at various levels, including the interplay among levels of governments. SES also brings forward the concept of panarchy (Holling 2001, Gunderson and Holling 2002) in which the social (human) and ecological (biophysical) subsystems are considered together as interdependent, coevolutionary, and linked through feedback loops (Norgaard 1994, Berkes et al. 1998). Understanding both impacts of human systems and resulting feedbacks from coupled social and ecological systems is critical for climate research and governance analysis. Ecological systems are the ultimate limiting factor for our continued existence and well-being, and thus the system dynamics described through SES shape the preconditions for transformation and our capacity to transform to a more sustainable state.

SES also introduces nuanced ways of looking at scale, spatially as well as temporally. The focus on multiple scales and cross-scalar effects allows for interrogation of "top-down" and "bottom-up" actions within a multilevel system, and the attention to crossscalar effects allows for units of analysis that are located at different positions on a scale (Gibson et al. 2000, Cash et al. 2006). In addition, the SES perspective recognizes that such system interactions can have nonlinear dynamics.

Perhaps the most important quality of SES in the context of researching development paths is that it presents systems interactions as occurring dynamically within a change continuum based on the adaptive cycle (Walker et al. 2004). This allows for an understanding of how development paths can operate or shift as systems enter different phases of growth/exploitation, accumulation/conservation, collapse/release, and renewal/ reorganization (Holling 2001), which is essential if temporality is to be captured in the analysis. This reinforces the idea that both social and ecological systems are not static and are in dynamic equilibrium, which is a notion that can reveal ways to inform policy development that could potentially reduce lock-in and path dependencies. In addition, the adaptive cycle fosters a clearer understanding of the cross-scale systems interactions involved in panarchy, such as "remember" and "revolt" interactions (Holling 2001). Respectively, these involve interactions where a larger system in the conservation phase can facilitate the renewal of a smaller system, and where a smaller system experiencing a critical change can stimulate a similar change in a larger system, i.e., revolt. Investigating the former can provide insights into how higher levels of government influence and provide context for local communities in the reorganization phase, and investigating the latter allows for insights on the influence of emergent ideas, and by proxy, niche and social innovations (Abidi-Habib and Lawrence 2007). Furthermore, the adaptive cycle illuminates the need for transformative change through its emphasis on release 
and reorganization, destabilization and emergent properties, often dampened down by socio-technical regimes.

\section{Multilevel perspective}

The systems approach to development paths is informed primarily by transition studies including strategic niche management (Kemp et al. 1998, Hoogma et al. 2002, Raven and Geels 2010), technological innovation systems (Hekkert et al. 2007, Bergek et al. 2008), transition management (Kern and Smith 2008, Loorbach 2010), and the multilevel perspective on transitions (Rip and Kemp 1998, Berkhout 2002, Geels 2004). Although operating in the same domain of system transitions, each area focuses on different system dynamics. Strategic niche management is concerned with purposive innovations at only the niche (or micro) level. Technological innovation systems thinking emphasizes technologies evolving within specific institutional and organizational contexts, while transition management merges technical transitions with Holling's (2001) complex adaptive systems theory and theories of governance (Rotmans et al. 2001, Smith et al. 2005). Finally, the MLP focuses on multiscalar interactions among three activity levels, i.e., landscape, regime, and niche. Its emphasis on multiple, simultaneous interactions within and between scales, and reconciliation of both micro- and macro-scale action make the MLP particularly well suited to analyzing development paths and differing levels of government policy development.

Unlike the panarchy perspective taken by SES (Berkes et al. 1998, Gunderson and Holling 2002, Norgaard 2010), an MLP perspective assumes a more hierarchical structure, which is useful for analyzing development paths because it captures relationships between levels of government and socioeconomic activities. It also can be used to examine institutional structures and relations to illuminate whether higher level government policies (or the actions of a regime) mesh with existing local adaptations to climate variations, or conversely, undermine them (Young et al. 2008, Adger et al. 2011). This is important information for optimizing government policy (Dale 2008, 2015).

With respect to changing a development path, the MLP conceptualizes the stable regime as the deep structural level, or "conglomerate of structure (institutional and physical setting), culture (prevailing perspective), and normative practices (rules, routines, and habits)" (Rotmans and Loorbach 2009:185). In simple terms the regime can be thought of as the status quo in society, or a reflection of a collective understanding of how things are normally done. The regime not only provides the rule sets and resources that guide actors, but it is also the product of collective actions by agents (Geels 2011), in much the same way that social practices are both the medium and outcome of social structures (Schatzki 2001). This is an important distinction made by the MLP as it denies the presence or absence of a single cause or driver behind transitions, and instead points to "circular causality," or the idea that transitions come about as a result of multiple, simultaneous processes in multiple dimensions and at different levels (Geels 2011:29). Geels (2011) argues that radical reconfiguration of the regime is critical for development path reorientation yet involves synergistic action at all three levels. Dale and colleagues (2015) similarly argue that policy congruence is necessary between and among levels of government.
Niche-level experiments create new ways of doing and thinking that sometimes change the orientation of regime values and rules (Geels 2005, 2011). Experimentation and innovation in niches protected from the regime and supported by powerful groups can sometimes generate momentum and alter regime rules and values, and possibly reconfigure regime foundations if additional pressure, from the landscape level or regime itself, are exerted (Geels 2005, Geels and Schot 2007, Rotmans and Loorbach 2009). It is our contention that transformative change for climate action in a development path cannot occur unless niche innovations disrupt and penetrate the socio-technical regime level, and are ultimately supported, congruently by actions at both the regime and landscape levels. As an example, the growing (normative) acceptance of electric vehicles today relies on simultaneous action at all three levels: technological experimentation at the niche level, i.e., marketing of hybrid and full-electric models; global climate (cultural) concerns at the landscape level related to fossil fuel intensive transport; and, realignment of regime values regarding the material benefits, i.e., improved air quality, emissions reductions, energy security/autonomy, from transitioning away from fossil fuel-powered vehicles.

MLP also provides a useful means for analyzing how change might be influenced and governed in the context of climate action. This approach has valuable application for climate action research because as stated earlier, we are interested in the ability to deliberately intervene for change, and how development paths can be intentionally influenced to support climate solutions. For example, Schroth et al. (2011) convened a collaborative adaptive planning workshop in Entlebuch, Switzerland which involved a discussion on decreasing snow cover in the local mountains and its potential impacts on an economy dependent on ski tourism. This led to a consensus that economic diversification is needed, which entailed deliberate changes in the local economic system and also community identity, i.e., changing from a ski town to another identity.

Although the MLP perspective is largely apolitical, some MLP scholars address issues of power, control and conflict, by making regime power and dominance explicit. Grin et al. (2010) locate different forms of power at each of the MLP's three levels: relational power-niche experiments; dispositional power-regime; structural power-landscape. To be clear, we are interested in power as it is manifested via established practices and associated rules at the institutional and regime level, rather than the individual and subjective levels. Although the MLP presents power as an inherent quality of the regime and does not explain the causal mechanisms behind it, its utility is in acknowledging the ways in which power is maintained and distributed within regime structures, that is, by fostering and defending collective values, goals, and internal logics through institutional arrangements and normative practice. Through this perspective, we can interrogate whether for example, the regime is more hostile to transformative change than lower level orders and how such hostilities might impact the potential for local level change. In a similar vein, MLP allows for an investigation of the influences exogenous variables have on local government change dynamics. SES, of course, also addresses the influence of exogenous variables and MLP applies this to interactions at different levels of societal organization. This is important for understanding how constrained communities are 
by these variables and what they can do to break free from these constraints.

\section{Social practice theories}

The key epistemological contributions made by social practice theories concern the actor-structure interdependence, the intelligent force of society, shared but tacit consensus on values and understanding, the observation that social institutions are constituted by intersubjective interactions, and the importance of material artifacts in structuring agency (Bourdieu 1977, Schatzki 1997). In opposition to both structuralism and rationalism, practices are the unit of social analysis, and it is through these events that the individual is defined and structural forces empowered. We propose to traverse this binary just as Giddens (1984:2) does when he proposes that our role as social scientists is to study, "neither the experience of the individual actor, nor the existence of any form of social totality, but social practices ordered across space and time." The literature includes a variety of definitions of social practices, but Reckwitz's contribution offers one of the most explicit definitions. He suggests a social practice is,

a routinized type of behavior which consists of several elements, interconnected to one another: forms of bodily activities, forms of mental activities, 'things' and their use, a background knowledge in the form of understanding, know-how, states of emotion and motivational knowledge (Reckwitz 2002:249).

Spaargaren et al. (2016) boil down the most commonly referenced definitions into one comprehensive definition, which proposes that social practices are,

[s]hared, routinized, ordinary ways of doing and saying, enacted by knowledgeable and capable agents who - while interacting with the material elements that co-constitute the practice - know what to do next in a non-discursive, practical manner (Spaargaren et al. 2016: 8).

Together, these two definitions help characterize the place of free will and agency in transformative social processes, as they emphasize the hanging together and inseparability of practices from the capacity of skilled actors to make sense of the social world and express internal emotions and will.

The elements constituting practices - materials, competence, and meaning - are central to the ways in which practices emerge, evolve, persist, transform, disappear, and reappear (Schatzki 2012, Shove et al. 2012). Wholesale changes to the constituent elements of a practice, or the relations between bundled practices, are required for development path change. Therefore, examining practice elements and the linkages between practices can yield fruitful insights into disaggregating technological lock-in and path dependence.

In the practice-centered view of society, actors follow rules, obey norms, and comprehend meaning through their tacit knowledge and performance of practices, and by doing so, they breathe further life into the structures that dispose them to perform the practices in the first place. Human cognitions are not the site of the social, yet actors do play a role in social processes as carriers and interpreters of practice entities (Schatzki 2012). Practices endure and evolve over time thanks to unconsciously compliant humans who perform act after act in accordance with the unwritten rules practices engender (Collins 2001, Schatzki 2001). However, actor obedience is not without limits. We subscribe to Røpke's (2009) view that, far from being loyal slaves, actors express their agency via their cognitive, physical, and interpretive skills during practice performances. An individual's skills reflect individual and collective notions of place, changing values, and teleo-affective goals, but they are not static. Thus, they result in slightly different practice performances over time that can give rise to new practices. These performance permutations reflect the degree to which a practice's internal logic and structure is tacitly recognizable, and hence adoptable by an actor. In this way, SPT accounts for the agency and individual values within socio-technical and socialecological change dynamics, but it does so in a way that limits the reach of individual cognitions.

The conceptual gap between a single practice, or even practice bundle, and processes of technological lock-in is significant. Practice theories provide insights into how discrete human activities are linked to larger scale social change, and action at various scales and levels. We define development paths praxeologically as a complex array of intertwined, mutually reinforcing, and coevolving practice bundles, e.g., automobility, consumption, international trade, education, etc., performed through space and time. In effect, a praxeological view of the world permits us to reorient our attention toward the activity, e.g., driving or walking, energy consumption or conservation, purchasing locally or purchasing imported goods, rather than the person doing it. By focusing on how practices and practice bundles form and evolve, rather than on individuals who perform practices, we gain a fresh perspective on social change dynamics. This is why we see value in linking practice theory with MLP concepts of niche, regime and landscape, and social-ecological systems thinking.

\section{TOWARD AN INTEGRATIVE FRAMEWORK}

Interrogating development path dynamics, requires a suitably flexible and fluid framework. Such an analytical approach, we suggest, should account for the complex characteristics of development paths, such as multiple scales of action and interaction, power dynamics, institutional dynamics, nonlinearity and ecological feedbacks, spatial embeddedness, and the fundamental reliance their inertia has on individual actions and understandings. To this point, we have unpacked the discrete contributions that the three theoretical approaches make to understanding development path change. Now we examine the areas of crossover and synergy between the three approaches in an effort to move toward a novel and integrative framework that can be used to illuminate the processes that determine development path stability and change. To be clear, we do not argue for a full integration of SPT, MLP, and SES because each has its own internal logic and epistemological concerns. Rather, we suggest that interrogating development path dynamics using vocabulary and concepts borrowed from these frames can help to paint a more complete picture of the diversity of scale, institutional and actor interactions, and social-ecological feedbacks involved.

When considering the nature of socio-technical and socialecological systems through the three lenses, we find sites of interconnection and crossover, but perhaps more importantly, we see how they complement one another. With respect to the 
functioning of networks and relations between discrete actors, we acknowledge the earlier work of Bodin and Norberg (2005), Olsson et al. (2006), and Crona and Parker (2012) to conceptualize the role of networks in adaptive ecosystem management, and work that has examined networks in the SES context (Beilin et al. 2013, Nabavi and Daniell 2017). We contend, however, that these theoretical perspectives in themselves do not fully address how the formation and dynamics of relationships between individual actors and groups can lead to changing path dynamics. For this, we turn to social practice theory and the multilevel perspective because they are well positioned to address the notion of networks, i.e., practice bundles and complexes, socio-technical regimes, and cross-scale interactions, and their respective constellations of relations and varying degrees of stability (Geels 2010, Shove et al. 2012). Conversely, fundamental issues such as resource depletion and ecosystem failures are explicitly addressed through SES's emphasis on the important relations between human systems and their impacts on ecosystem cycles and services, whereas they are only handled tangentially by SPT and MLP. In this way, SES compensates for SPT and MLP, both of which have little to say about ecological feedback dynamics, while SPT and MLP can do the same for SES in terms of networks and actors.

\section{Space and place}

With respect to spatiality, practice theories understand practices as "open-ended spatially-temporally dispersed nexus of sayings and doings" (Schatzki 2012:14), which potentially situates them anywhere and everywhere in space and not in explicitly hierarchical levels like those seen in systems of governance and economies. SPT does, however, highlight the spatial embeddedness of individual and institutional actions, which aligns well with the role of place in determining climate action and policy. MLP is criticized by some for not adequately accommodating spatial issues, but we agree with Murphy's (2015) findings that suggest the interactions and couplings among niche, regime, and landscape levels are fundamentally shaped by sociospatial processes. SES is substantially concerned with space and place, providing concepts regarding interactions between spaces, e.g., ecosystems, environments, economic zones, the urban, etc., each with its own socially constructed meaning. Stedman (2016) warns of the highly subjective nature of meanings of place, including spaces in the natural environment, in social-ecological systems thinking. We agree with his proposition that people, not places, create a sense of place via a "proliferation of place meanings" (Stedman 2016:896).

\section{Agency}

The role of agents in social change and development path trajectories, is highly contested. One view is that humans are free, autonomous actors who provide the primary motive force behind social change, while another perspective portrays human actors as "faceless automata" (Geels 2004) or "cultural dopes" (Giddens 1984), obliged to perform static functions and follow fixed rules that they cannot change. We take a Giddensian approach that attempts to bridge this either/or binary. Giddens' (1984) notion of the duality of structure allows structures to be both product and medium of intersubjective actions performed by agents who knowledgeably and actively deploy rule systems to negotiate their worlds within the constraints of those same structures. This framing of agency aligns with Geels' (2004) conceptualization in the MLP where actors ingest and express values, and the argument of Spaargaren et al. (2016:8) that actors simply "know what to do next in a non-discursive practical way." Although SES is criticized (Stedman 2016) for not engaging with the inherent subjectivity of social-ecological systems, the current authors take insights from actor network theory and recognize the distributed agency (Rammert 2008) of human and nonhuman actors, e.g., landscapes, artifacts, etc., all of which figure prominently in ecological system stability. Social practice theories, therefore, adhere to this notion of constrained agency and the messy world of intersubjective interactions, where actors are highly knowledgeable about the fields within which they operate, despite not necessarily being able to vocalize their cognitions or all of their goals and motivations. SPT therefore proposes that individuals interpret practice performances according to both structuring forces and routines maintained by internal rule sets. The result is slight mutations to discrete practice events, yet importantly, these performance mutations leave the original practice intelligible to others, and available to reinforce larger societal structures. Each of the three frames deals with agency in a different way, but in doing so, they triangulate with each other to create a fuller picture of actors than any one frame could provide by itself.

\section{Actor and institutional relations}

Turning to the important question of how relations between regime actors are developed, maintained, or altered, we find the MLP provides only a superficial explanation. SPT compensates for this shortcoming by allowing us to apply a practice lens to the various socio-technical systems constituting the regime level. By doing so, we can conceive of these socio-technical systems as groupings of practice complexes, i.e., groups of tightly bound, coevolved, and codependent practices. Practice complexes, which drive circuits of reproduction, constitute powerful social projects, i.e., coevolved institutions in stable regimes, and often outcompete fledgling practices for loyal actors, just as hostile regimes impede novelties and niche experiments from flourishing easily. Similarly, a niche experiment discussed in MLP terms can be understood at a more detailed level by SPT as an example of reconfiguring relations between existing practice elements, or indeed, as a new configuration of practice elements.

The nonlinear trajectories and feedback effects inherent in development paths are not well addressed by MLP and SPT, yet SES thinking and Holling's adaptive cycle can help fill this gap and explain how social-ecological systems tend to move sequentially, powered by feedback effects, through different phases of growth, conservation, release, and reorganization. Further, multilevel governance is considered by many as vital to shift toward more sustainable community development (Dale et al. 2018), while to a lesser degree, MLP usefully conceptualizes scalar interrelations between and among institutions, both governmental and non.

\section{Power}

Whereas MLP and SES tend to represent power in rather abstract terms as a given or constant in any socio-technical or socialecological system, SPT helps us understand the mechanisms by which power and influence can actually grow and consolidate within a regime, that is, through ever larger numbers of actors adopting and maintaining loyalty to a particular practice or 
bundle of practices. The question of why some practices or ideas gain more traction than others can be explained praxeologically. At a subjective level, SPT tells us that an actor's decision to adopt a practice, and thereby contribute to its overall influence in a regime, reflects the recognizability or meaning embedded within the practice, and whether or not the actor possesses the requisite skills and materialities to perform the practice successfully (Schatzki 2001). Framing power dynamics in this way raises important questions about the mechanisms by which intersubjective relations help establish and maintain power within a regime. Concerns about the variability and dominance of particular meanings, expressed by socially accepted actor roles and established power dynamics, overlap nicely with practice theories that emphasize socially understandable performances, and the MLP that draws attention to those meanings that are deemed acceptable, and hence reproducible in any given system.

Within socio-technical and social-ecological spheres we find diverse actors interacting, ranging from individuals and institutions to objects and entire landscapes. The challenge is to disaggregate these influences. Therefore, although SPT helps us understand the role that individuals play collectively in maintaining dominant practices, creating new practices, and contributing to regime stability or innovation, our approach expands on the list of usual suspects by implicating institutions, industrial sectors, i.e., via MLP, as well as systems and species of the nonhuman world, i.e., via SES. In this way, our framework allows objects and nonhumans to be understood variably depending on the context within which they are found, that is, as either integral elements in a practice performance, as technologies, as physical contributors to sense making and meaning, or as part of the environment within which system interactions unfold. We suggest that this sort of triangulation using the three approaches broadens the scope of analysis, and enhances our understanding of development path change. Table 1 summarizes the relative strengths of each framework with respect to power, scale, agency, and place.

Table 1. Strengths and weaknesses of multilevel perspective (MLP), social-ecological systems (SES), and social practice theories (SPT).

\begin{tabular}{lccc}
\hline \hline & MLP & SES & SPT \\
\hline Power and politics & ++ & + & ++ \\
Scalar interactions & +++ & ++ & NA \\
Agency (human and & ++ & + & ++ \\
nonhuman) & & & \\
Place and space & NA & +++ & + \\
\hline
\end{tabular}

\section{Applying the integrative framework}

We intend to apply this framework to forthcoming case study research. This will be part of a research project, the Meeting the Climate Change Challenge ( $\mathrm{MC}^{3}$; http://mc-3.ca/), which examines local community climate innovations in the Canadian province of British Columbia (BC). BC was selected as a focus for $\mathrm{MC}^{3}$ because the province has engaged in a suite of policies and initiatives that have encouraged local climate action, such as the voluntary Climate Action Charter for local governments to reduce carbon emissions and the Green Communities legislation
(Bill 27) that amended the Local Government Act in 2008, mandating that climate policies and strategies be included in official community plans (Berkhout and Westerhoff 2013, Dale et al. 2013, Burch et al. 2014). These provincial initiatives have spurred innovation and action at the local level, and using a contextual, comparative case study research methodology (Stake 1995, Yin 2002), $\mathrm{MC}^{3}$ studied these actions/innovations in $11 \mathrm{BC}$ communities.

The $\mathrm{MC}^{3}$ case study research was conducted in 2012, and we plan to revisit the case study communities with the intention of using the framework detailed in this paper for examining community development paths. As previously mentioned, we do not fully integrate SPT, MLP, and SES; rather, we employ them in a complementary fashion to develop a more comprehensive picture of scalar interactions, actors, power, and place. Our methodology involves semistructured interviews using an interview protocol that draws from each of theoretical lenses, which is a similar approach to that presented by Foxon et al. (2009) for examining different change management/governance frameworks, i.e., adaptive management and transition management. Interview questions drawing from SES will capture relationships between humans and nature, as well as the ecological dynamics that affect these relationships. Questions drawing from MLP will elucidate relationships and interactions between different levels of government and actors, as well as the internal logic and values of the regime. Questions drawing from SPT will concern practicesas-entities both in the local government and community. Table 2 provides sample questions that could be included in this proposed interview protocol.

Because Table 2 only captures sample questions, it is not a comprehensive representation of the framework outlined in this paper. However, what Table 2 does demonstrate is that although our framework interrogates complex ideas, its methodological application is relatively straightforward, consisting of a series of interview questions developed through each of the three theoretical lenses. The key consideration of this approach is to avoid attempts to unify and reconcile differences between the three theoretical streams examined in this paper, and instead, simply investigate through each of these lenses to create a single dataset that captures all three perspectives.

\section{CONCLUSIONS}

COP 21 in Paris saw world leaders, the business sector, and civil society agreeing that fundamental societal transformations are needed to avoid catastrophic impacts of climate change. National commitments will not be enough to meet the targets established in Paris. But what kinds of transformations and shifts in practices, cultures, and human ecological relations will be sufficient and how will they be stimulated and achieved? How can we understand what is needed at the local level and what entry points could lead to effective change? Shifting current development paths will require profound understanding of multiscale interactions, social practices, and path dependencies, as well as the nature of sociotechnical and social ecological systems and their potential for change. No one currently employed analytical perspective can achieve this alone. We contend that a combination of the approaches and perspectives operating at different levels of societal organization discussed in this paper will lead to deeper understanding of these variables and point the way to 
Table 2. Sample interview questions for interrogating change.

\begin{tabular}{|c|c|}
\hline Theoretical lens & Sample questions \\
\hline $\begin{array}{l}\text { Social-ecological systems } \\
\text { (SES) }\end{array}$ & $\begin{array}{l}\text { Have you observed any improvements to the ecological capital in your community? } \\
\text { In what ways do your existing plans and planning processes take into account both human and ecological } \\
\text { well-being in your community, and do your plans acknowledge and protect ecosystem services (for } \\
\text { example, do their plans include food security)? } \\
\text { Have any of your innovations contributed to increased understanding of the importance of ecological } \\
\text { integrity in the community? }\end{array}$ \\
\hline $\begin{array}{l}\text { Multilevel perspective } \\
\text { (MLP) }\end{array}$ & $\begin{array}{l}\text { How important and in what ways was provincial legislation, policies, incentives, and mandated reporting to } \\
\text { your local climate action? } \\
\text { How influential were external actors and existing networks in triggering community or organizational } \\
\text { change since we last interviewed you? (prompt for norms, rules, and practices) } \\
\text { Are there influencing forces or drivers, beyond your local government's control and influence that affect } \\
\text { how and what climate/sustainability decisions are made in your municipality? }\end{array}$ \\
\hline $\begin{array}{l}\text { Social practice theory } \\
\text { (SPT) }\end{array}$ & $\begin{array}{l}\text { Can you describe any behavioral changes in your organization and the community that have happened } \\
\text { since we last interviewed you? } \\
\text { What specific institutional (policies or programs) or social changes in your community have you observed } \\
\text { as a response to the implementation of your climate action since the last time we interviewed you? } \\
\text { How influential do you feel you can be with respect to changing or altering the "rules of the game" in your } \\
\text { organization, and can you give us an example(s)? }\end{array}$ \\
\hline
\end{tabular}

transformation and effective long-term action in response to climate change.

We, like others (Geels 2005, Geels and Schot 2007, Frantzeskaki and de Haan 2009, Williams 2016) are skeptical that transformation to sustainability only starts in niches at the local level, and that wider social changes and regime shift transformations are driven or emerge from these. In forthcoming research, we plan to explore key questions around change, in particular, if change emerges from the niche level, and even if it influences change at the socio-technical regime level while the landscape level remains the same, is transformative change possible? Given the characteristics of climate change, it is our assertion that only if congruent change happens at all three levels, that transformative change such as moving to carbon neutral economies is likely to occur. That transformative change for climate change adaptation and mitigation might only happen if all three levels align is indeed a sobering thought and a significant challenge.

Responses to this article can be read online at: http://www.ecologyandsociety.org/issues/responses. php/10029

\footnotetext{
Acknowledgments:

The authors would like to thank Professor John Robinson (University of Toronto) and Emily Huddart Kennedy, Assistant Professor (Washington State University) for their very helpful comments and feedback on earlier drafts of this paper. We also gratefully acknowledge the Social Sciences and Humanities Research Council of Canada for its support of our research project, Meeting the Climate Change Challenge (MC3).
}

\section{LITERATURE CITED}

Abidi-Habib, M., and A. Lawrence. 2007. Revolt and remember: how the Shimshal Nature Trust develops and sustains socialecological resilience in northern Pakistan. Ecology and Society 12 (2):35. http://dx.doi.org/10.5751/ES-02246-120235

Adger, W. N., J. Barnett, F. S. Chapin III, and H. Ellemor. 2011. This must be the place: underrepresentation of identity and meaning in climate change decision-making. Global Environmental Politics 11:1-25. http://dx.doi.org/10.1162/GLEP_a_00051

B Team. 2015. B Team open letter calls for bold climate action at COP21 in Paris. [online] URL: http://bteam.org/the-b-team/bteam-open-letter-calls-for-bold-climate-action-at-cop21-in-paris/

Beilin, R., N. T. Reichelt, B. J. King, A. Long, and S. Cam. 2013. Transition landscapes and social networks: examining on-ground community resilience and its implications for policy settings in multiscalar systems. Ecology and Society 18(2):30. http://dx.doi. org/10.5751/ES-05360-180230

Bergek, A., S. Jacobsson, B. Carlsson, S. Lindmark, and A. Rickne. 2008. Analyzing the functional dynamics of technological innovation systems: a scheme of analysis. Research Policy 37:407-429. http://dx.doi.org/10.1016/j.respol.2007.12.003

Berkes, F., J. Colding, and C. Folke, editors. 2002. Navigating social-ecological systems: building resilience for complexity and change. Cambridge University Press, Cambridge, UK. http://dx. doi.org/10.1017/CBO9780511541957

Berkes, F., C. Folke, and J. Colding, editors. 1998. Linking social and ecological systems: management practices and social mechanisms for building resilience. Cambridge University Press, Cambridge, UK.

Berkhout, F. 2002. Technological regimes, path dependency and the environment. Global Environmental Change 12:1-4. http://dx. doi.org/10.1016/S0959-3780(01)00025-5

Berkhout, T., and L. Westerhoff. 2013. Local energy systems: evaluating network effectiveness for transformation in British 
Columbia, Canada. Environmental Planning C: Politics and Space 31:841-857. http://dx.doi.org/10.1068/c11267

Betsill, M., and H. Bulkeley. 2007. Looking back and thinking ahead: a decade of cities and climate change research. Local Environment 12:447-456. https://doi.org/10.1080/13549830701659683 http://dx.doi.org/10.1080/13549830701659683

Bodin, Ö., and J. Norberg. 2005. Information network topologies for enhanced local adaptive management. Environmental Management 35:175-193. http://dx.doi.org/10.1007/s00267-004-0036-7

Bondizio, E. S., E. Ostrom, and O. R. Young. 2009. Connectivity and the governance of multilevel social-ecological systems: the role of social capital. Annual Review of Environment and Resources 34:253-278. http://dx.doi.org/10.1146/annurev.environ.020708.100707

Bourdieu, P. 1977. Outline of a theory of practice. Cambridge University Press, Cambridge, UK. http://dx.doi.org/10.1017/ CBO9780511812507

Brown, J. H., W. R. Burnside, A. D. Davidson, J. R. DeLong, W. C. Dunn, M. J. Hamilton, N. Mercado-Silva, J. C. Nekola, J. G. Okie, W. H. Woodruff, and W. Zuo. 2011. Energetic limits to economic growth. BioScience 61:19-26. http://dx.doi.org/10.1525/ bio.2011.61.1.7

Brown, H. S., and P. J. Vergragt. 2013. Grassroots innovations and socio-technical system change: energy retrofitting of the residential housing stock. Pages 154-176 in G. Marletto, editor. Creating a sustainable economy: an institutional and evolutionary approach to environmental policy. Routledge, London, UK. http:// dx.doi.org/10.4324/9780203117989

Bulkeley, H. 2005. Reconfiguring environmental governance: towards a politics of scales and networks. Political Geography 24:875-902. http://dx.doi.org/10.1016/j.polgeo.2005.07.002

Bulkeley, H. 2010. Cities and the governing of climate change. Annual Review of Environment and Resources 35:229-253. http:// dx.doi.org/10.1146/annurev-environ-072809-101747

Burch, S. 2010. In pursuit of resilient, low carbon communities: an examination of barriers to action in three Canadian cities. Energy Policy 38:7575-7585. http://dx.doi.org/10.1016/j.enpol.2009.06.070

Burch, S., A. Shaw, A. Dale, and J. Robinson. 2014. Triggering transformative change: a development path approach to climate change response in communities. Climate Policy 14:467-487. http://dx.doi.org/10.1080/14693062.2014.876342

Cash, D. W., W. N. Adger, F. Berkes, P. Garden, L. Lebel, P. Olsson, L. Pritchard, and O. Young. 2006. Scale and cross-scale dynamics: governance and information in a multilevel world. Ecology and Society 11(2):8. http://dx.doi.org/10.5751/ES-01759-110208

Castán Broto, V., and H. Bulkeley. 2013. A survey of urban climate change experiments in 100 cities. Global Environmental Change 23:92-102. http://dx.doi.org/10.1016/j.gloenvcha.2012.07.005

Collins, H. M. 2001. What is tacit knowledge? Pages 115-128 in K. D. Knorr-Cetina, E. V. Savigny, and T. R. Schatzki, editors. The practice turn in contemporary theory. Routledge, London, UK.

Cote, M., and A. J. Nightingale. 2012. Resilience thinking meets social theory: situating social change in socio-ecological systems
(SES) research. Progress in Human Geography 36:475-489. http:// dx.doi.org/10.1177/0309132511425708

Crona, B. I., and J. N. Parker. 2012. Learning in support of governance: theories, methods, and a framework to assess how bridging organizations contribute to adaptive resource governance. Ecology and Society 17(1):32. http://dx.doi. org/10.5751/ES-04534-170132

Dale, A. 2008. Governance for sustainable development: as if it mattered? Pages 54-71 in G. Toner and J. Meadowcroft, editors. Innovation, science and environment 2009-2010. Special EditionCharting Sustainable Development in Canada 1987-2007. McGillQueen's University Press, Montréal, Québec, Canada.

Dale, A. 2015. Prioritizing policy. Alternatives Journal 41.1:76-79.

Dale, A., S. Burch, J. Robinson, and C. Strashok. 2018. Multilevel governance of sustainability transitions in Canada: policy alignment, innovation, and evaluation. Climate Change in Cities: Innovations in Multi-Level Governance 343-358. http://dx.doi. org/10.1007/978-3-319-65003-6 17

Dale, A., W. Dushenko, and P. J. Robinson. 2012. Urban sustainability: reconnecting space and place. University of Toronto Press, Toronto, Ontario, Canada.

Dale, A., and S. B. Hill. 2001. At the edge: sustainable development in the 21st Century. University of British Columbia Press, Vancouver, British Columbia, Canada.

Dale, A., R. Newell, Y. Herbert, and R. Foon. 2015. The solutions agenda: a call to action for and by Canadians. Research Project Report. Royal Roads University, Victoria, British Columbia, Canada. [online] URL: https://www.crcresearch.org/solutionsagenda- 0

Dale, A., and L. Newman. 2007. Governance for integrated resource management. Pages 56-71 in K. S. Hanna and D. S. Slocombe, editors. Integrated resource and environmental management: concepts and practice. Oxford University Press, Oxford, UK.

Dale, A., J. Robinson, J. Herbert, and A. Shaw. 2013. Climate change adaptation and mitigation: an action agenda for B.C. decision-makers. Action Agenda. Royal Roads University, Victoria, British Columbia, Canada. [online] URL: https:// crcresearch.org/solutions-agenda/climate-action-agenda-bc-decision$\underline{\text { makers }}$

Davidson, C. 2000. Economic growth and the environment: alternatives to the limits paradigm. BioScience 50:433-440. http:// dx.doi.org/10.1641/0006-3568(2000)050[0433:EGATEA]2.0.CO;2

Folke, C., T. Hahn, P. Olsson, and J. Norberg. 2005. Adaptive governance of social-ecological systems. Annual Review of Environment and Resources 30:441-473. http://dx.doi.org/10.1146/ annurev.energy.30.050504.144511

Foxon, T. J., M. S. Reed, and L.C. Stringer. 2009. Governing longterm social-ecological change: what can the adaptive management and transition management approaches learn from each other? Environmental Policy and Governance 19:3-20. http://dx.doi. org/10.1002/eet.496 
Frantzeskaki, N., and H. de Haan. 2009. Transitions: two steps from theory to policy. Futures 41:593-606. http://dx.doi. org/10.1016/j.futures.2009.04.009

Frantzeskaki, N., D. Loorbach, and J. Meadowcroft. 2012. Governing societal transitions to sustainability: transition management as a governance approach towards pursuing sustainability. International Journal of Sustainable Development 15(1-2). http://dx.doi.org/10.1504/IJSD.2012.044032

Future Earth. 2014. Future Earth initial design. Future Earth.

Geels, F. W. 2004. From sectoral systems of innovation to sociotechnical systems: insights about dynamics and change from sociology and institutional theory. Research Policy 33:897-920. http://dx.doi.org/10.1016/j.respol.2004.01.015

Geels, F. W. 2005 The dynamics of transitions in socio-technical systems: a multi-level analysis of the transition pathway from horse-drawn carriages to automobiles (1860-1930). Technology Analysis and Strategic Management 17:445-476. http://dx.doi. org/10.1080/09537320500357319

Geels, F. W. 2010. Ontologies, socio-technical transitions (to sustainability), and the multi-level perspective. Research Policy 39:495-510. http://dx.doi.org/10.1016/j.respol.2010.01.022

Geels, F. W. 2011. The multi-level perspective on sustainability transitions: responses to seven criticisms. Environmental Innovations and Societal Transitions 1:24-40. http://dx.doi. org/10.1016/j.eist.2011.02.002

Geels, F. W. 2014. Regime resistance against low-carbon transitions: introducing politics and power into the multi-level perspective. Theory Culture and Society 31:21-40. http://dx.doi. org/10.1177/0263276414531627

Geels, F. W., and J. Schot. 2007. Typology of sociotechnical transition pathways. Research Policy 36:399-417. http://dx.doi. org/10.1016/j.respol.2007.01.003

Gibson, C. C., E. Ostrom, and T. K. Ahn. 2000. The concept of scale and the human dimensions of global change: a survey. Ecological Economics 32:217-239. http://dx.doi.org/10.1016/ $\underline{\text { S0921-8009(99)00092-0 }}$

Giddens, A. 1984. The constitution of society. Outline of the theory of structuration. Polity Press, Cambridge, UK.

Gillard, R., A. Gouldson, J. Paavola, and J. Van Alstine. 2016. Transformational responses to climate change: beyond a systems perspective of social change in mitigation and adaptation. Wiley Interdisciplinary Review on Climate Change 7:251-265. http://dx. doi.org/10.1002/wcc.384

Grin, J., J. Rotmans, and J. Schot. 2010. Transitions to sustainable development: new directions in the study of long term transformative change. Routledge, New York, New York, USA.

Gunderson, L. H., and C. S. Holling, editors. 2002. Panarchy: understanding transformations in human and natural systems. Island Press, Washington, D.C., USA.

Hekkert, M. P., R. A. A. Suurs, S. O. Negro, and S. Kuhlmann, and R. E. H. M. Smits. 2007. Functions of innovation systems: a new approach for analysing technological change. Technological Forecasting and Social Change 74:413-432. http://dx.doi. org/10.1016/j.techfore.2006.03.002
Hertz, T., and M. Schlüter. 2015. The SES-framework as boundary object to address theory orientation in social-ecological system research: the SES-TheOr approach. Ecological Economics 116:12-24. http://dx.doi.org/10.1016/j.ecolecon.2015.03.022

Hodson, M., and S. Marvin. 2010. World cities and climate change. McGraw-Hill Education, Maidenhead, UK.

Holling, C. S. 2001. Understanding the complexity of economic, ecological, and social systems. Ecosystems 4:390-405. http://dx. doi.org/10.1007/s10021-001-0101-5

Holtz, G., M. Brugnach, and C. Pahl-Wostl. 2008. Specifying "regime": a framework for defining and describing regimes in transition research. Technological Forecasting and Social Change 75:623-643. http://dx.doi.org/10.1016/j.techfore.2007.02.010

Hoogma, R., R. Kemp, J. Schot, and B. Truffer. 2002. Experimenting for sustainable transport. The approach of strategic niche management. Spon Press, London, UK.

Intergovernmental Panel on Climate Change (IPCC). 2007. Climate change 2007: mitigation of climate change. Working Group III Contribution to the Fourth Assessment Report of the Intergovernmental Panel on Climate Change. B. Metz, O.R. Davidson, P.R. Bosch, R. Dave, L.A. Meyer, editors. Cambridge University Press, Cambridge, UK.

International Social Science Council (ISSC) and UNESCO. 2013. World social science report 2013: changing global environments. OECD Publishing and UNESCO Publishing, Paris, France.

Kemp, R., J. Schot, and R. Hoogma. 1998. Regime shifts to sustainability through processes of niche formation: the approach of strategic niche management. Technology Analysis and Strategic Management 10:175-198. http://dx.doi.org/10.1080/09537329808524310

Kemp, R. P. M., A. Rip, and J. W. Schot. 2001. Constructing transition paths through the management of niches. Pages 269-299 in R. Garud and P. Karnoe, editors. Path dependence and creation. Lawrence Erlbaum, Mahwa, New Jersey, USA.

Kern, F., and A. Smith. 2008. Restructuring energy systems for sustainability? Energy transition policy in the Netherlands. Energy Policy 36:4093-4103. http://dx.doi.org/10.1016/j.enpol.2008.06.018

Latour, B. 2005. Reassembling the social: an introduction to actornetwork-theory. Clarendon lectures in management studies. Clarendon, Oxford, UK.

Levin, K., B. Cashmore, S. Bernstein, and G. Auld. 2012. Overcoming the tragedy of super wicked problems: constraining our future selves to ameliorate global climate change. Policy Sciences 45:123-152. http://dx.doi.org/10.1007/s11077-012-9151-0

Loorbach, D. 2010. Transition management for sustainable development: a prescriptive, complexity-based governance framework. Governance 23:161-183. http://dx.doi.org/10.1111/ j.1468-0491.2009.01471.x

Loorbach, D., and J. Rotmans. 2010. Towards a better understanding of transitions and their governance: a systemic and reflexive approach. Pages 105-222 in J. Grin, J. Rotmans, and J. Schot, editors. Transitions to sustainable development: new directions in the study of long term transformative change. Routledge, New York, New York, USA. 
Lutz, J., and J. Schachinger. 2013. Do local food networks foster socio-ecological transitions towards food sovereignty? Learning from real place experiences. Sustainability 5:4778-4796. http://dx. doi.org/10.3390/su5114778

Markard, J., R. Raven, and B. Truffer. 2012. Sustainability transitions: an emerging field of research and its prospects. Research Policy 41:955-967. http://dx.doi.org/10.1016/j.respol.2012.02.013

Moore, M. L., O. Tjornbo, E. Enfors, C. Knapp, J. Hodbod, J. A. Baggio, A. Norström, P. Olsson, and D. Biggs. 2014. Studying the complexity of change: toward an analytical framework for understanding deliberate social-ecological transformations. Ecology and Society 19(4):54. http://dx.doi.org/10.5751/ ES-06966-190454

Mühlemeier, S., and C. R. Binder. 2016. Conceptualising urban energy supply systems as socio-technical ecological systems in transition, in: GORDON Research Conference, Industrial Ecology. Ecole Polytechnique Federale de Lausanne, Lausanne, Switzerland.

Muñoz-Erickson, T. 2014. Multiple pathways to sustainability in the city: the case of San Juan, Puerto Rico. Ecology and Society 19(3):2. http://dx.doi.org/10.5751/ES-06457-190302

Murphy, J. T. 2015. Human geography and socio-technical transition studies: promising intersections. Environmental Innovation and Societal Transitions 17:73-91. http://dx.doi. org/10.1016/j.eist.2015.03.002

Murray, G., and L. King. 2012. First nation values and protected area governance: Tla-o-qui-aht Tribal Parks and Pacific Rim National Park Reserve. Human Ecology 40:385-395. http://dx.doi. org/10.1007/s10745-012-9495-2

Nabavi, E., and K. A. Daniell. 2017. Rediscovering socialecological systems: taking inspiration from actor-networks. Sustainability Science 12:621-629. http://dx.doi.org/10.1007/ $\underline{\text { s11625-016-0386-0 }}$

Norgaard, R. B. 1994. Development betrayed: the end of progress and a co-evolutionary revisioning of the future. Routledge, London, UK.

Norgaard, R. B. 1995. Metaphors we might survive by. Ecological Economics 15:129-131. http://dx.doi.org/10.1016/0921-8009(95) 00068-2

Norgaard, R. B. 2010. Ecosystem services: from eye-opening metaphor to complexity blinder. Ecological Economics 69:1219-1227. http://dx.doi.org/10.1016/j.ecolecon.2009.11.009

Olsson, P., C. Folke, and F. Berkes. 2004. Adaptive comanagement for building resilience in social-ecological systems. Environmental Management 34:75-90. http://dx.doi.org/10.1007/s00267-003-0101-7

Olsson, P., L. H. Gunderson, S. R. Carpenter, P. Ryan, L. Lebel, C. Folke, and C. S. Holling. 2006. Shooting the rapids: navigating transitions to adaptive governance of social-ecological systems. Ecology and Society 11(1):18. http://dx.doi.org/10.5751/ ES-01595-110118

Patterson, J., K. Schulz, J. Vervoort, S. van der Hel, O. Widerberg, C. Adler, M. Hurlbert, K. Anderton, M. Sethi, and A. Barau. 2017. Exploring the governance and politics of transformations towards sustainability. Environmental Innovation and Societal Transitions 24:1-16. http://dx.doi.org/10.1016/j.eist.2016.09.001

Rammert, W. 2008. Where the action is: distributed agency between humans, machines, and programs. Working Paper No. TUTSWP-4-2008. Technology Studies. University of Bielefeld, Bielefeld, Germany. http://dx.doi.org/10.14361/9783839408421-004

Raven, R. P. J. M., and F. W. Geels. 2010. Socio-cognitive evolution in niche development: comparative analysis of biogas development in Denmark and the Netherlands (1973-2004). Technovation 30:87-99. http://dx.doi.org/10.1016/j. technovation.2009.08.006

Reckwitz, A. 2002. Toward a theory of social practices: a development in culturalist theorizing. European Journal of Social Theory 5:243-263. http://dx.doi.org/10.1177/13684310222225432

Rip, A., and R. Kemp. 1998. Technological change. Pages 327-399 in S. Rayner and E. L. Malone, editors. Human choice and climate change. Battelle Press, Columbus, Ohio, USA.

Rockström, J., W. Steffen, K. Noone, Å Persson, F. S. Chapin III, E. F. Lambin, T. M. Lenton, M. Scheffer, C. Folke, H. J. Schellnhuber, B. Nykvist, C. A. de Wit, T. Hughes, S. van der Leeuw, H. Rodhe, S. Sörlin, P. K. Snyder, R. Costanza, U. Svedin, M. Falkenmark, L. Karlberg, R. W. Corell, V. J. Fabry, J. Hansen, B. Walker, D. Liverman, K. Richardson, P. Crutzen, and J. A. Foley. 2009. A safe operating space for humanity. Nature 461:472-475. https://doi.org/10.1038/461472a http://dx.doi. org/10.1038/461472a

Røpke, I. 2009. Theories of practice - new inspiration for ecological economic studies on consumption. Ecological Economics 68:2490-2497. http://dx.doi.org/10.1016/j.ecolecon.2009.05.015

Rotmans, J., R. Kemp, and M. van Asselt. 2001. More evolution than revolution: transition management in public policy. Foresight 3:15-31. http://dx.doi.org/10.1108/14636680110803003

Rotmans, J., and D. Loorbach. 2009. Complexity and transition management. Journal of Industrial Ecology 13:184-196. http://dx. doi.org/10.1111/j.1530-9290.2009.00116.X

Schatzki, T. R. 1997. Practices and actions: a Wittgensteinian critique of Bourdieu and Giddens. Philosophy of the Social Sciences 27:283-308. http://dx.doi.org/10.1177/004839319702700301

Schatzki, T. R. 2001. Practice theory. Pages 10-24 in K. D. KnorrCetina, E. V. Savigny, and T. R. Schatzki, editors. The practice turn in contemporary theory. Routledge, London, UK.

Schatzki, T. R. 2012. A primer on practices: theory and research. Pages 13-26 in J. Higgs, R. Barnett, S. Billett, M. Hutchings, and F. Trede, editors. Practice-based education: perspectives and strategies. Sense Publishers, Rotterdam, The Netherlands. http:// dx.doi.org/10.1007/978-94-6209-128-3 2

Schroth, O., U. W. Hayek, E. Lange, S. R. J. Sheppard, and W. A. Schmid. 2011. Multiple-case study of landscape visualizations as a tool in transdisciplinary planning workshops. Landscape Journal 30:53-71. http://dx.doi.org/10.3368/1j.30.1.53

Shaw, A., S. Burch, F. Kristensen, J. Robinson, and A. Dale. 2014. Accelerating the sustainability transition: exploring synergies between adaptation and mitigation in British Columbian 
communities. Global Environmental Change 25:41-51. http://dx. doi.org/10.1016/j.gloenvcha.2014.01.002

Shove, E., M. Pantzar, and M. Watson. 2012. The dynamics of social practice: everyday life and how it changes. SAGE, London, UK. http://dx.doi.org/10.4135/9781446250655

Shove, E., and G. Walker. 2007. Caution! Transitions ahead: politics, practice, and sustainable transition management. Environmental Planning A: Economy and Sustainable 39:763-770. http://dx.doi.org/10.1068/a39310

Smith, A., A. Stirling, and F. Berkhout. 2005. The governance of sustainable socio-technical transitions. Research Policy 34:1491-1510. http://dx.doi.org/10.1016/j.respol.2005.07.005

Smith, A., J.-P. Voß, and J. Grin. 2010. Innovation studies and sustainability transitions: the allure of the multi-level perspective and its challenges. Research Policy 39:435-448. http://dx.doi. org/10.1016/j.respol.2010.01.023

Spaargaren, G., D. Weenink, and M. Lamers. 2016. Practice theory and research: exploring the dynamics of social life. Routledge, London, UK.

Stake, R. E. 1995. The art of case study research. SAGE, Thousand Oaks, California, USA.

Stedman, R. C. 2016. Subjectivity and social-ecological systems: a rigidity trap (and sense of place as a way out). Sustainability Science 11:891-901. http://dx.doi.org/10.1007/s11625-016-0388y

The Elders. 2015. The Elders urge world leaders to take bold and decisive action on climate in 2015. Press release. The Elders, 4 September. [online] URL: http://theelders.org/article/elders-urgeworld-leaders-take-bold-and-decisive-action-climate-2015

United Nations Framework Convention on Climate Change (UNFCCC). 2015. Adoption of the Paris Agreement. Conference of the Parties, Twenty-first session. Paris, France.

Unruh, G. C. 2000. Understanding carbon lock-in. Energy Policy 28:817-830. http://dx.doi.org/10.1016/S0301-4215(00)00070-7

Vergragt, P. J., and H. S. Brown. 2012. The challenge of energy retrofitting the residential housing stock: grassroots innovations and socio-technical system change in Worcester, MA. Technology Analysis and Strategic Management 24:407-420. http://dx.doi. org/10.1080/09537325.2012.663964

Walker, B., C. S. Holling, S. R. Carpenter, and A. Kinzig. 2004. Resilience, adaptability and transformability in social-ecological systems. Ecology and Society 9(2):5. http://dx.doi.org/10.5751/ ES-00650-090205

Westley, F. R., O. Tjornbo, L. Schultz, P. Olsson, C. Folke, B. Crona, and Ö. Bodin. 2013. A theory of transformative agency in linked social-ecological systems. Ecology and Society 18(3):27. http://dx.doi.org/10.5751/ES-05072-180327

Williams, J. 2016. Can low carbon city experiments transform the development regime? Futures 77:80-96. http://dx.doi.org/10.1016/ j.futures.2016.02.003

Wolfram, M., and N. Frantzeskaki. 2016. Cities and systemic change for sustainability: prevailing epistemologies and an emerging research agenda. Sustainability 8(2):144. http://dx.doi. org/10.3390/su8020144

World Wildlife Fund for Nature (WWF). 2011. The energy report. WWF, Gland, Switzerland.

Yin, R. K., 2002. Case study research: design and methods. Third Edition. SAGE Publications Thousand Oaks, California, USA.

Young, O. R., L. A. King, and H. Schroeder, editors. 2008. Institutions and environmental change: principal findings, applications, and research frontiers. MIT Press, Boston, Massachusetts, USA. 